Jurnal BASTRA (Bahasa dan Sastra) : http://ojs.uho.ac.id/index.php/BASTRA

\title{
KRITIK SOSIAL PADA LIRIK LAGU IWAN FALS (SUATU KAJIAN SOSIOLOGI KARYA SASTRA)
}

\author{
OLEH \\ Vizci Ayu Lestari ${ }^{1}$, La Ode Balawa ${ }^{2}$, dan Aris Badara ${ }^{3}$ \\ ${ }^{1}$ Alumni Jurusan Pend. Bahasa dan Sastra Indonesia, ${ }^{2,3}$ Dosen Jurusan Pendidikan \\ Bahasa dan Sastra Indonesia, Fakultas Keguruan dan Ilmu Pendidikan \\ Universitas Halu Oleo
}

\begin{abstract}
ABSTRAK
Masalah yang dikaji dalam penelitian ini adalah bagaimanakah kritik sosial pada lirik lagu Iwan Fals (suatu kajian sosiologi karya sastra)?Tujuan yang ingin dicapai dalam penelitian ini adalah untuk mendeskripsikan kritik sosial pada lirik lagu Iwan Fals (suatu kajian sosiologi karya sastra).Manfaat dalam penelitian ini adalah (1) sebagai salah satu rujukan para guru dan siswa dalam rangka peningkatan dan pencapaian peningkatan pembelajaran bahasa dan sastra Indonesia (2) bagi masyarakat umum, diharapkan muncul suatu wawasan baru dari masyarakat bahwa sebuah karya sastra dalam bentuk lagu dapat menciptakan bahwa banyak hal yang terjadi tidak berjalan dengan semestinya seperti kejahatan, penyelewengan, dan kemiskinan yang seharusnya mendapat perhatian dan pemikiran semua lapisan masyarakat agar keadaan jauh lebih baik (3) sebagai bahan masukan bagi para peneliti sastra yang relevan dengan penelitian ini. Penelitian ini menggunakan metode deskriptif kualitatif.Jenis penelitian yaitu penelitian perpustakaan (library research).Data yang digunakan dalam penelitian ini adalah data tertulis dan berfokus pada empat lirik lagu Iwan fals yang mengandung kritik sosial yang berjudul Tikustikus Kantor, Sarjana Muda, Surat Buat Wakil Rakyat, dan Ambulance Zigzag.Sumber data dalam penelitian ini adalah kumpulan lagu Iwan Fals yang dikutip dari youtube.Teknik pengumpulan data, yaitu teknik baca dan teknik catat.Teknik analisis data, yaitu identifikasi data, klasifikasi data, deskripsi data, analisis data, dan interpretasi data.Data penelitian ini dianalisis dengan menggunakan pendekatan sosiologi karya sastra.Hasil penelitian ini menunjukan kritik sosial yang terdapat pada lirik lagu Iwan Fals, antara lain; (1) kritik sosial terhadap korupsi; (2) kritik sosial terhadap penegak hukum; (3) kritik sosial terhadap pengangguran; (4) kritik sosial terhadap kinerja anggota dewan; (5) kritik sosial terhadap diskriminasi pelayanan kesehatan.
\end{abstract}

Kata Kunci: kritik sosial, lirik lagu, sosiologi, karya sastra 


\section{PENDAHULUAN}

\subsection{Latar Belakang}

Kritik sosial adalah salah satu bentuk komunikasi dalam masyarakat yang bertujuan atau berfungsi sebagai kontrol terhadap jalannya suatu sistem sosial. Kritik sosial terdiri dari dua istilah yakni dari kata kritik dan sosial. Dalam pengertian Kamus Besar Bahasa Indonesia dijelaskan bahwa kritik ialah suatu kecaman atau tanggapan serta uraian dan pertimbangan baik buruk suatu hasil karya, pendapat dan sebagainya. Pengertian sosial memiliki arti berteman, bersama, berserikat, yang bermaksud untuk mengerti kejadian-kejadian dalam masyarakat yaitu persekutuan manusia, untuk dapat berusaha mendatangkan perbaikan dalam kehidupan bersama.

Sastra pada umumnya menampilkan gambaran kehidupan sosial tertentu.Sastra berada di tengah masyarakat yang muncul karena desakan-desakan emosional atau rasional dari masyarakat.Sastra mencerminkan persoalan sosial yang ada dalam masyarakat dan pengarang memiliki taraf kepekaan yang tinggi dalam menerjemahkan realitas sosial.Karya sastra juga mencerminkan kritik sosial yang barangkali tersembunyi.

Iwan Fals yang bernama lahir Virgiawan Listanto yang lahir di Jakarta, pada tanggal 3 September 1961 adalah seorang penyanyi beraliran Balada, Pop, Rock, dan Country yang menjadi salah satu penyanyi legenda di Indonesia serta banyak meciptakan lagu-lagu mengenai keadaan sosial. Lewat lagu-lagunya, ia 'memotret' suasana sosial kehidupan Indonesia pada akhir tahun70-an hingga sekarang, kehidupan dunia pada umumnya, dan kehidupan itu sendiri. Kritik atas perilaku sekelompok orang seperti pada lagu Wakil Rakyat, Tante Lisa, empati bagi kelompok marginal misalnyalagu Siang Seberang Istana, atau bencana besar yang melanda
Indonesia atau kadang-kadang di luar Indonesia, seperti Ethiopia mendominasi tema lagu-lagu yang dibawakannya.

Seorang pengarang mempunyai banyak pandangan dibalikkarya yang diciptakannya. Pemahaman isi karya sastra yang ditulis pengarang bergantung pada ketajaman interpretasi pembaca atau pendengarnya. Untukdapat menginterpretasikan karya sastra dengan baik, pembaca harus memahami dengan sungguh-sungguh maksud pengarang dalam karya yang dihasilkannya itu.

Lagu merupakan rangkaian kata demi kata yang disusun sedemikian rupa sehingga mengandung irama dan makna yang bertujuan untuk menyampaikan pesan kebanyak orang terhadap suatu objek. Lagu juga merupakan perilaku sosial yang memuat pikiran manusia, gagasan, dan ideide yang mengandung pesan yang signifikan. Muatan lagu tidak hanya sebuah gagasan untuk menghibur melainkan memiliki pesan-pesan moral sekaligus memiliki kekuatan ekonomis serta kritikkritik sosial.

Lirik lagu merupakan ekspresi seorang pengarang dalam menyampaikan sesuatu hal kepada pendengarnya dengan cara dilihat atau didengarkan. Setiap lirik lagu pasti memiliki makna yang ingin disampaikan kepada pendengar dengan menggunakan permainan kata atau diksi yang dimiliki oleh seorang pengarang karena setiap pengarang memiliki daya tarik tersendiri dan kekhasan dalam menciptakan lagu. Bahasa dalam lirik diseleksi sedemikian rupa sehingga menjadi indah dan mampu memberikan ketepatan makna, nuansa, serta daya estetika. Hal inilah yang membuat lirik lagu juga kaya akan gaya bahasa.

Kritiksosial yang dituangkan dalam lagu oleh para musisi bertujuan membawa penikmat atau pendengar lagu ke arah sikap mental dan tata nilai yang diharapkan 
pengarang.Sehingga pendengar lagu dapat termotivasi untuk berbuat yang terbaik dalam mengembalikan tatanankehidupan sosial kepada hal yang semestinya berlaku.Selain itu juga bertujuan mengecam ketimpangan-ketimpangan yang terjadi dalam masyarakat tertentu, juga mengharapkan agar ketimpanganketimpangan sosial dapat dihilangkan atau dikurangi.

Sosiologi karya sastra yaitu mengkaji isi karya sastra, tujuan, serta hal-hal yang lain yang tersirat dalam karya sastra itu sendiri dan yang berkaitan dengan masalah sosial. Oleh karena itu pemilihan sosiologi karya sastra sebagai teori penelaahan dianggap relevan dengan objek dan masalah penelitian.

Penelitian dengan objek kajian pada lirik lagu karya Iwan Fals sudah dilakukan oleh beberapa peneliti lainnya seperti penelitian yang dilakukan oleh Muhammad Isnaedhi (2015) dalam skripsinya dengan judul Perkembangan Lirik Lagu-Lagu Iwan Fals Sebagai Kritik Sosial Terhadap Pemerintah Orde Baru, Jahrudin (2015) dengan judul Kritik Pembangunan Lagu Iwan Fals dalam Implikasinya Terhadap Pembembelajaran Bahasa Indonesia di SMA Kelas XII, dan Santi Widia Puspitasari (2010) dengan judul Kritik Sosial dalam Lirik Lagu (Studi Semiotik tentang Pemaknaan Lirik Lagu "Besar dan Kecil" Karya Iwan Fals.

Dengan menggunakan data-data tersebut, peneliti dapat untuk menghindari duplikasi, dan sebagai penentuan posisi penelitian ini terhadap penelitian sejenis yang lain. Maka dari itu dari beberapa datadata di atas peneliti dapat melihat perbedaan dengan peneliti yang sebelumnya maupun penelitian yang akan dilakukan. Perbedaan yang terdapat dari penelitian yang telah dilakukan adalah pada fokus penelitiannya serta pada lirik lagu. Peneliti berfokus pada kritik sosial pada lirik lagu Iwan Fals dengan menggunakan suatu kajian sosiologi sastra.

Dalam penelitian ini peneliti akan mendeskripsikan kritik sosial pada lirik lagu Iwan Fals dengan menggunakan suatu kajian sosiologi karya sastra dalam hal ini menganalisis beberapa lirik lagu karya dari Iwan Fals yaitu lirik lagu dengan judul Tikus-tikus Kantor, Sarjana Muda, Surat Buat Wakil Rakyat, dan Ambulance Zig-zag. Dalam penelitian ini peneliti akan melakukan penelitian dengan menganalisis lirik lagu karya Iwan Fals dengan mendeskripsikan kritik sosial yang terkandung dalam lirik lagu tersebut.

Dalam penelitian ini penulis mengambil lagu-lagu karya Iwan Fals untuk dijadikan sebagai bahan penelitian. Dalam hal ini peneliti mengambil beberapa lagu dari Iwan fals yang memuat tentang kritik sosial yang sering terjadi di masyarakat Indonesia, yaitu mengambil lirik lagu dengan judul Tikus-tikus Kantor, Sarjana Muda, Surat Buat Wakil Rakyat, dan Ambulance Zig-zag untuk dijadikan sebagai bahan penelitian. Lagu-lagu tersebut memuat kritik kondisi sosial yang sangat dekat dan kontekstual dengan kondisi masyarakat Indonesia saat ini.

Dalam lirik lagu tersebut juga sangat menarik untuk dianalisis, karena keempat lirik lagu tersebut sudah mewakili dari problema atau hal-hal sosial bangsa yang banyak dipermasalahkan di Indonesia dari semenjak lagu tersebut diciptakan hingga sekarang ini. Misalnya seperti yang terjadi di lingkungan sosial masyarakat kita saat ini, yaitu terdapat banyaknya masalah sosial seperti adanya korupsi yang belum bisa diatasi sampai tuntas, persengkongkolan dan molornya kinerja anggota dewan, ketidakadilan terhadap hukum yang bisa dikatakan kondisi hukum di Indonesia saat ini yaitu tajam ke bawah tumpul keatas,

432 |Jurnal BASTRA (Bahasa dan Sastra), Vol. 4 No. 3, Edisi Juli 2019/e-ISSN: 2503-3875/ http://ojs.uho.ac.id/index.php/BASTRA 
kondisi ekonomi yang makin hari makin memburuk dapat dilihat dengan banyaknya pengangguran dimana-mana serta lowongan pekerjaan yang disediakan oleh pemerintah sangatlah minim dan layanan publik yang masih mendiskriminasikan antara rakyat miskin dan kaya. Kritik sosial yang menjadi fokus dalam penelitian ini berangkat dari kenyataan sosial yang ada, khususnya yang ada di Negara Indonesia saat ini yaitu kritik sosial terhadap politik, ekonomi, dan hukum.

Dalam menganalisis sebuah karya sastra khususnya lagu perlu adanya sebuah pendekatan. Pendekatan disini digunakan sebagai suatu cara agar penelitian menjadi lebih dalam. Pendekatan merupakan sebuah cara yang digunakan peneliti untuk menguasai dan mengembangkan ilmu yang paling tinggi validitasnya dan ketepatannya sebagai acuan dalam penelitian. Berkaitan dengan penelitian mengenai kritik sosial pada lirik lagu Iwan Fals, dalam hal ini peneliti menggunakan pendekatan sosiologi karya sastra untuk menelaah lagu-lagu tersebut.

Sosiologi sastra merupakan perkembangan dari pendekatan mimesis yang memahami karya sastra dalam hubungannya dengan realitas dan aspek sosial kemasyarakatan.Sosiologi sastra dilatarbelakangi oleh fakta bahwa keberadaan sastra tidak terlepas dari realitas sosial yang terjadi dalam masyarakat.

Menurut Wellek dan Werren ada tiga pendekatan yang berbeda dalam sosiologi sastra, yaitu sosiologi yang pengarang memasalahkan status sosial, ideologi sosial, dan lain-lain yang menyangkut pengarang sebagai penghasil karya sastra, sosiologi karya sastra yang memasalahkan karya sastra itu sendiri, dan sosiologi sastra yang memasalahkan pembaca dan pengaruh sosial karya sastra. Berdasarkan tiga pendekatan sosiologi sastra tersebut, maka dalam penelitian ini peneliti menggunakan pendekatan sosiologi karya sastra.

Mengkaji kritik sosial pada lirik lagu Iwan Fals (suatu kajian sosiologi karya sastra) dilakukan agar dapat mengetahui kritik sosial apa yang terkandung dalam lirik lagu Iwan Fals. Penelitian ini penting dilakukan karena sangat erat kaitannya terhadap penanaman nilai sosial dan pembentukan kepribadian manusia, dengan mengetahui ketimpangan-ketimpangan atau kritik sosial yang terjadi dalam kehidupan masyarakat, maka kita akan tumbuh sebagai pribadi yang peduli terhadap lingkungan sosial.

\subsection{RumusanMasalah}

Berdasarkan uraian dalam latar belakang di atas, maka yang menjadi masalahdalam penelitian ini adalah bagaimanakah kritik sosial pada lirik lagu Iwan Fals (suatu kajian sosiologi karya sastra)?

\subsection{Tujuan Penelitian}

Berdasarkan pokok permasalahan tersebut maka tujuan penelitian ini adalah untuk mendeskripsikan kritik sosial pada lirik lagu Iwan Fals (suatu kajian sosiologi karya sastra).

\subsection{Manfaat Penilitian}

Adapun manfaat yang diharapkan dalam penelitian ini adalah sebagai berikut:

1. Sebagai salah satu rujukan para guru dan siswa dalam rangka peningkatan dan pencapaian peningkatan pembelajaran bahasa dan sastra Indonesia.

2. Bagi masyarakat umum, diharapkan muncul suatu wawasan baru dari masyarakat bahwa sebuah karya sastra dalam bentuk lagu dapat menciptakan bahwa banyak hal yang terjadi tidak berjalan dengan semestinya seperti kejahatan, penyelewengan, dan kemiskinan yang seharusnya mendapat 
perhatian dan pemikiran semua lapisan masyarakat agar keadaan jauh lebih baik.

3. Sebagai bahan masukan bagi para peneliti sastra yang relevan dengan penelitian ini.

\section{KAJIAN PUSTAKA}

\subsection{Hakikat Karya Sastra}

Redaksi PM (2012: 2) menyatakan bahwa dalam artian kesusastraan, sastra bisa dibagi menjadi sastra tertulis atau sastra lisan (sastra oral).Di sini sastra tidak banyak berhubungan dengan tulisan, tetapi dengan bahasa yang dijadikan wahana untuk mengekspresikan pengalaman atau pemikiran tertentu.Suatu hasil karya baru dapat dikatakan memiliki nilai sastra bila di dalamnya terdapat kesepadanan antara bentuk dan isinya.Bentuk bahasanya baik dan indah, dan susunanya beserta isinya dapat menimbulkan perasaan haru dan kagum di hati pembacanya.

Wicaksono (2014: 1) menyatakan bahwa karya sastra merupakan ungkapan batin seseorang melalui bahasa dengan cara penggambaran yang merupakan titian terhadap kenyataan hidup, wawasan pengarang terhadap kenyataan kehidupan, imajinasi murni pengarang yang tidak berkaitan dengan kenyataan hidup (rekaman peristiwa) atau dambaan intuisi pengarang, dan dapat pula sebagai campuran keduanya.

Selden (dalam Siswanto, 2008: 92) menyatakan bahwa karya sastra tidak mempunyai keberadaan nyata sampai karya sastra itu dibaca.Pembacalah yang menerapkan kode yang ditulis sastrawan untuk menyampaikan pesan.Damono (dalam Wicaksono, 2014: 1) menyatakan bahwa karya sastra menampilkan gambaran kehidupan dan kehidupan itu sendiri adalah suatu kenyataan sosial.

Sangidu (dalam Wicaksono, 2014: 2) menyatakan bahwa sastra adalah bagian dari masyarakat, kenyataan yang demikian mengilhami para pengarang untuk melibatkan dirinya dalam tata kehidupan masyarakat tempat mereka berada dan mencoba memperjuangkan posisi struktur sosial dan permasalahan yang dihadapi di masyarakat.

Karya sastra yang ditulis merupakan ungkapan masalah-masalah manusia dan kemanusiaan, tentang makna hidup dan kehidupan, melukiskan penderitaanpenderitaan manusia, perjuangannya, kasih sayang dan kebencian, nafsu, dan segala yang dialami manusia, Esten (dalam Wicaksono, 2014: 3).

Horacedalam Wellek dan

Warren(dalam Wicaksono,2014: 4) mengemukakan bahwa fungsi karya sastra adalah dulce atutile yang artinya menyenangkan dan berguna.Menyenangkan dalam arti tidak menjemukan, tidak membosankan.Berguna dalam arti tidak membuang-buang waktu, bukan sekedar perbuatan iseng melainkan sesuatu yang perlu mendapatkan perhatian serius.

Berdasarkan pendapat yang dikemukakan oleh para ahli diatas, maka dapat disimpulkan bahwa karya sastra merupakan suatu imajinasi, ungkapan batin, kenyataan hidup, pengalaman kehidupan seorang sastrawan yang dituangkan dalam bentuk karya tulisan maupun dalam karya sastra lisan yang sebagai potret kehidupan masyarakat.Kenyataan itulah yang mengilhami para pengarang untuk melibatkan dirinya dalam tata kehidupan masyarakat tempat mereka berada dan memperjuangkan posisi struktur sosial dan permasalahan yang dihadapi di masyarakat sehingga dapat dinikmati, dipahami, dan dapat dimanfaatkan oleh masyarakat.

\subsection{Definisi Lirik Lagu}

Lirik lagu merupakan ekspresi seseorang tentang suatu hal yang sudah dilihat, didengar maupun dialaminya.Dalam 
mengekspresikan pengalamannya, penyair atau pencipta lagu melakukan permainan kata-kata dan bahasa untuk menciptakan daya tarik dan kekhasan terhadap lirik atau syairnya. Permainan bahasa ini berupa permainan vokal, gaya bahasa maupun penyimpangan makna kata dan diperkuat dengan penggunaan melodi dan notasi musik yang disesuaikan dengan lirik lagunya sehingga pendengar semakin terbawa dengan apa yang dipikirkan pengarangnya, Awe (dalam Hidayat, 2014: 246-247).

Definisi lirik atau syair lagu dapat dianggap sebagai puisi begitu pula sebaliknya.Hal serupa juga dikatakan oleh Jan Van Luxemburg (dalam Hidayat, 2014: 247) yaitu definisi mengenai teks-teks puisi tidak hanya mencakup jenis-jenis sastra melainkan juga ungkapan yang bersifat pepatah, pesan iklan, semboyan-semboyan politik, syair-syair lagu dan doa-doa.

Dari pendapat tersebut, dapat disimpulkan bahwa lirik lagu merupakan ekspresi seorang penyair dari dalam batinnya tentang sesuatu yang sudah dilihat, didengar maupun di alami.Lirik lagu mempunyai kesamaan dengan sajak hanya saja dalam lirik lagu juga mempunyai kekhususan tersendiri karena penuangan ide lewat lirik lagu diperkuat dengan melodi dan jenis irama yang disesuaikan dengan lirik lagu dan warna suara penyanyinya.

\subsection{Kritik Sosial}

Menurut Hardjana (dalam Pradopo, 2007: 182) kata kritik ini berasal dari bahasa Yunani Kuno krites yang berati hakim, dari kata kerja krinein yang artinya dasar menghakimi, yang merupakan pangkal kata kritikos yang berarti penghakiman, dan dari ini timbul kata kritikos yang berarti hakim karya sastra. Jadi, berdasarkan hal tersebut di atas kritik sastra itu berarti penghakiman karya sastra.Menghakimi berarti menentukan baik buruk sesuatu hal kesusastraan, begitulah pengertian kritik sastra.Hal tersebut seperti dikatakan oleh H.B. Jassin (dalam Pradopo, 2007: 182) bahwa kritik kesusastraan adalah pertimbangan baik atau buruk sesuatu hasil kesusastraan, dengan alasan-alasan mengenai isi dan bentuk hasil kesusastraan.

Menurut Marbun (dalam Santoso, 2014: 50) bahwa kritik sosial merupakan frase yang terdiri dari dua kata yaitu kritik dan sosial.Adapun yang dimaksud dengan kritik adalah suatu tanggapan atau kecaman yang kadang-kadang disertai dengan uraian dan pertimbangan baik maupun burukya suatu hasil karya, pendapat, dan sebagainya. Sementara di sisi lain, Webster (dalam Santoso, 2014: 50) menjelaskan bahwa kata kritik berasal dari bahasa Latin criticus atau bahasa Yunani kritikos yang berarti a judge atau dari kata kinnea yang berarti tojudge.

Kritik sosial adalah salah satu bentuk komunikasi dalam masyarakat yang bertujuan atau berfungsi sebagai kontrol terhadap jalannya suatu sistem sosial atau proses bermasyarakat. Penekanan dalam pengertian ini adalah control terhadap sebuah sistem sosial atau proses bermasyarakat yang merupakan realita sosial. Kritik sebagai salah satu bentuk komunikasi pada dasarnya adalah sebuah cara menyampaikan ketidaksetujuannya terhadap realita yang ada, Abar (dalam Aliyah, 2010: 20).

Dari beberapa pendapat diatas maka dapat disimpulkan bahwa kritik sosial adalah suatu bentuk komunikasi dalam masyarakat yang berfungsi sebagai kontrol terhadap jalannya suatu sistem atau proses bermasyarakat dan juga sebagai suatu protes sosial.

\subsection{Kajian Kritik Sosial}

Kajian kritik sosial menurut Sodikin (dalam Aliyah, 2010 :21) yaitu politik, 
ekonomi, hukum, budaya, dan pertahanan keamanan. 1) Politik yaitu hal-hal yang berkaitan dengan negara, kekuasaan, pengambilan keputusan, kebijaksanaan dan pembagian wewenang atau alokasi. 2) Ekonomi yaitu segala hal berkaitan dengan distribusi pembagian rezeki atau pencaharian. 3) Budaya yaitu semua aspek yang berkaitan dengan cipta, rasa dan karsa manusia sebagai manusia yang beradab. 4) Pertahanan keamanan yaitu segala usaha yang berkaitan dengan pertahanan dan usaha menciptakan kondisi yang aman. 5) Hukum yaitu hal-hal yang berkaitan dengan tata aturan atau perundang-undangan.

Dengan demikian kajian kritik sosial dalam penelitian ini juga bersandar pada penjelasan kajian kritik sosial di atas.

\subsection{Pendekatan Sosiologi}

\subsubsection{Sosiologi Sastra}

Sosiologi sastra berasal dari kata sosiologi dan sastra.Sosiologi berasal dari akar kata sosio (Yunani) (socius berarti bersama-sama, bersatu, kawan, teman) dan logi (logos berarti sabda, perkataan, perumpamaan).Perkembangan berikutnya mengalami perubahan makna, soio/socius berarti masyarakat, logi/logos berarti ilmu.Jadi, sosiologi berarti ilmu mengenai asal-usul dan pertumbuhan (evolusi) masyarakat, ilmu pengetahuan yang mempelajari keseluruhan jaringan hubungan antarmanusia dalam masyarakat, sifatnya umum, rasional, dan empiris.Sastra dari akar kata sas (Sansekerta) berarti mengarahkan, mengajar, memberi petunjuk dan instruksi.Akhiran tra berarti alat, sarana.Jadi, sastra berarti kumpulan alat untuk mengajar, buku petunjuk atau buku pengajaran yang baik.Makna kata sastra bersifat lebih spesifik sesudah terbentuk menjadi kata jadian, yaitu kesusastraan, artinya kumpulan hasil karya yang baik (Ratna, 2009: 1-2).
Ritzer (dalam Faruk, 2017 :2) menganggap sosiologi sebagai suatu ilmu pengetahuan yang multiparadigma. Maksudnya, didalam ilmu tersebut dijumpai beberapa paradigma yang saling bersaing dalam usaha dalam merebut hegemoni dalam lapangan sosiologi secara keseluruhan.

Berdasarkan pendapat yang dikemukakan oleh para ahli diatas, maka dapat disimpulkan bahwa sosiologi sastra adalah telaah yang mengkaji tentang hubungan keberadaan sastra yang tidak terlepas dari realitas sosial yang ada dalam masyarakat.

\subsubsection{Pendekatan Dalam Sosiologi Sastra}

Damono (dalam Faruk, 2017: 5) mengemukakan beberapa pendapat mengenai aneka ragam pendapat mengenai aneka ragam pendekatan terhadap karya sastra seperti yang di kemukakan Wolff diatas. Dari Wellek dan Werren ia menemukan setidaknya tiga jenis pendekatan yang berbeda dalam sosiologi sastra, yaitu

1. Sosiologi yang pengarang yang memasalahkan status sosial, ideologi sosial dan lain-lain yang menyangkut pengarang sebagai penghasil karya sastra, karena setiap pengarang adalah warga masyarakat, ia dapat dipelajari sebagai makhluk sosial.

2. Sosiologi karya sastra yang mempermasalahkan karya sastra itu sendiri yang menjadi pokok penelaahaanya atau apa yang tersirat dalam karya sastra dan apa yang menjadi tujuannya.

3. Sosiologi sastra yang memasalahkan pembaca dan pengaruh sosial karya sastra, pengarang dipengaruhi dan mempengaruhi masyarakat. 
Klasifikasi sosiologi sastra dari Wellek dan Warren inilah yang akan digunakan dalam penelitian ini tentang kritik sosial pada lirik lagu Iwan Fals, yaitu menggunakan pendekatan sosiologi karya sastra, yang menitik beratkan pada sastra yang mempermasalahkan karya sastra itu sendiri dan yang menjadi pokok penelaahan adalah apa yang tersirat dalam karya sastra dan apa yang menjadi tujuan.

\subsection{Sastra dan Masyarakat}

Hubungan sastra dan masyarakat adalah mempelajari sastra sebagai dokumen sosial, sebagai potret kenyataan sosial.Ada semacam potret sosial yang bisa ditarik dari karya sastra.Thomas Warton berusaha membuktikan bahwa sastra mempunyai kemampuan merekam ciri-ciri zamannya.Sebagai dokumen sosial, sastra dipakai untuk menguraikan ikhtisar sejarah sosial.Sastra dikaitkan dengan situasi tertentu, atau dengan sistem politik, ekonomi, dan sosial tertentu.

Hal ini dilakukan untuk menjabarkan pengaruh masyarakat terhadap sastra dan kedudukannya dalam masyarakat.Pendekatan sosiologis ini dipakai oleh pendukung filsafat sosial tertentu. Hubungan sastra dan masyarakat secara deskriptif dapat diklasifikasikan sebagai berikut: pertama adalah sosiologi pengarang, profesi pengarang, dan institusi sastra. Masalah yang berkaitan disini adalah dasar ekonomi produksi sastra, latar belakang sosial, status pengarang, dan ideologi pengarang yang terlihat dari berbagai kegiatan pengarang di luar sastra.Kedua adalah isi karya sastra itu sendiri dan yang berkaitan dengan masalah sosial.Dan ketiga adalah permasalahan pembaca dan dampak sosial karya sastra.Sejauh mana sastra ditentukan atau tergantung dari latar sosial, perubahan dan perkembangan sosial (Wellek dam Warren, 2016: 89-110).

\section{METODE DAN TEKNIK PENELITIAN 3.1 Metode dan Jenis Penelitian}

Metode yang digunakan dalam penelitian ini adalah metode deskriptif kualitatif.Metode deskriptif dapat diartikan sebagai penyajian data secara terurai berdasarkan kenyataan-kenyataan objektif sesuai dengan data yang terdapat dalam objek penelitian.

Jenis penelitian yang digunakan dalam penelitian ini adalah penelitian perpustakaan (library research) yakni penelitian yang dilakukan di kamar kerja peneliti atau di ruang perpustakaan yang di mana peneliti memperoleh data dan informasi tentang objek telitiannya lewat buku-buku atau alat-alat audio visual lainnya (Semi, 1990: 8).

\subsection{Data dan Sumber Data}

Data yang digunakan dalam penelitian ini adalah data tertulis dan berfokus pada empat lirik lagu Iwan fals yang mengandung kritik sosial yang berjudul Tikus-tikus Kantor, Sarjana Muda, Surat Buat Wakil Rakyat, dan Ambulance Zig-zag. Sumber data dalam penelitian ini adalah kumpulan lagu Iwan Fals yang dikutip dari youtube (https://www.youtube.com/watch? $v=z H J i P 9$ I230E) diakses pada tanggal 13 maret 2019, dalam video tersebut memuat lagu yang berjumlahkan lima puluh lima lagu.

\subsection{Teknik Pengumpulan Data}

Teknik pengumpulan data dalam penelitian ini adalah teknik baca dan teknik catat.Teknik baca yaitu membaca teks lirik lagu yang berjudul Tikus-tikus Kantor, Sarjana Muda, Surat Buat Wakil Rakyat, dan Ambulance Zig-zag karya Iwan Fals.Selain itu penulis melakukan kegiatan membaca terhadap buku-buku yang relevan

\section{7 |Jurnal BASTRA (Bahasa dan Sastra), Vol. 4 No. 3, Edisi Juli 2019/e-ISSN: 2503-3875/}

http://ojs.uho.ac.id/index.php/BASTRA 
dengan penelitian ini sebagai rujukan dalam melakukakn analisis lebih jauh terhadap teks lirik lagu yang menjadi objek penelitian.

Teknik catat yaitu mencatat data atau informasi yang diperoleh dari hasil pembacaan mengenai kritik sosial yang ada dalam lirik lagu Iwan Fals tersebut.

\subsection{Teknik Analisis Data}

Data penelitian ini dianalisis dengan menggunakan pendekatan sosiologi sastra yaitu dengan menggunakan pendekatan sosiologi karya sastra. Selengkapnya teknik analisis data yang dimaksud dilakukan dengan tahapan sebagai berikut:

1. Identifikasi data, maksudnya data yang sudah ada diberi kode sesuai dengan permasalahan kritik sosial.

2. Klasifikasi data, yaitu mengklasifikasi (mengelompokan) kritik sosial dalam lirik lagu Iwan Fals.

3. Deskripsi data, yaitu gambaran data dalam bentuk kutipan yang akan dipaparkan dalam bentuk pembahasan.

4. Analisis data, yaitu menganalisis data dengan metode yang sudah ditentukan, yakni metode deskriptif kualitatif.

5. Interpretasi data, yaitu memberikan gambaran secara umum tentang hasil penelitian yang diperoleh, hal tersebut tampak pada simpulan hasil penelitian

\section{HASIL PENELITIAN DAN} PEMBAHASAN

\subsection{Lirik Lagu Iwan Fals}

Fokus penelitian dalam penelitian ini yaitu terfokus pada empat lirik lagu Iwan Fals yang berjudul Tikus-tikus Kantor, Sarjana Muda, Surat Buat Wakil Rakyat, dan Ambulance Zig-zag.

\subsection{Kritik sosial pada lirik lagu Iwan Fals 4.2.1 Kritik Sosial Terhadap Korupsi}

Dari keempat lirik lagu Iwan Fals yang menjadi fokus penelitian dalam penelitian ini, terdapat satu lirik lagu yang mengandung tentang kritik sosial terhadap korupsi yaitu terdapat pada lirik lagu Iwan Fals yang berjudul Tikus-tikus Kantor.

Kritik sosial terhadap korupsi pada lirik lagu tersebut terdapat pada bait ke satu sampai dengan bait ketiga. Pada bait kesatu yaitu.

Kisah usang tikus tikus kantor

Yang suka berenang di sungai yang kotor Kisah usang tikus tikus berdasi

Yang suka ingkar janji lalu sembunyi

Pada bait tersebut pengarang menggambarkan tikus-tikus kantor dan tikus-tikus berdasi sebagai pejabat pemerintah yang koruptor. Koruptor diidentikkan dengan tikus yang suka pada lingkungan yang kotor, sama halnya dengan koruptor yang menyukai pekerjaanpekerjaan yang kotor.

Selain itu pada bait tersebut juga menjelaskan tentang pejabat pemerintah yang selalu melakukan tindakan korupsi dengan menyalahgunakan wewenangnya untuk mengambil uang negara dan membuat rakyat menderita. Pada bait tersebut terdapat lirik yang suka ingkar janji lalu sembunyi, yang menjelaskan tentang pejabat pemerintah yang selain melakukan tindakan korupsi juga suka menyampaikan janji manis pada rakyat saat berkampanye. Tetapi saat terpilih dan menjabat, mereka hilang tenggelam dalam persembunyian sehingga lupa dan tidak peduli akan janji yang mereka sampaikan pada rakyat. Pikiran untuk memperhatikan masyarakat kecil tidak ada.Semua tertuju pada pemikiran bahwa kebutuhan mereka lebih penting dari pada memikirkan kondisi rakyat miskin yang tidak mampu untuk mencukupi kebutuhan hidupnya. Pada bait keduayaitu.

Dibalik meja teman sekerja

Didalam lemari dari baja

Pada bait keduamenjelaskan tentang pejabat koruptor yang biasa berlindung di balik kekuatan teman lainnya yang memiliki kekuasaan untuk melindungi dirinya setelah melakukan praktik-praktik korupsi yang 
dijamin tidak akan tersentuh oleh hukum yang ada. Perbuatan mereka selalu tertutup rapi karena mereka telah bekerja sama dengan orang tempat mereka berlindung. Pada bait ketiga yaitu.

Kucing datang cepat ganti muka

Segera menjelma bagai tak tercela

Masa bodoh hilang harga diri

Asal tak terbukti ah tentu sikat lagi

Pada bait ketiga di atas menjelaskan bahwa sikap para pejabat koruptor yang begitu mudah dan naifnya saat para penegak hukum datang dan mengetahui aksi mereka, maka dengan cepatnya para pejabat tersebut mengubah sifatnya dari penjahat menjadi pejabat yang baik dan seolah-olah pejabat yang bersih dari tindak korupsi. Selain itu para pejabat koruptor tidak peduli akan harga dirinya, mereka membiarkan apa saja atas penilaian orang lain terhadapnya. Hal yang paling penting bagi dirinya adalah bisa mendapatkan uang sebanyak mungkin untuk kepentingan dirinya sendiri. Perilaku sang koruptor akan terus berlanjut selama aksinya tidak dapat dibuktikan oleh penegak hukum.

Penjelasan dari ketiga bait lirik lagu yang berjudul Tikus-tikus Kantor karya Iwan Fals tersebut maka dapat disimpulkan bahwa pada lirik lagu tersebut mengandung kritik sosial terhadap korupsi. Lirik lagu tersebut juga sangat berhubungan dengan keadaan masyarakat Indonesia saat ini khususnya di bidang politik yaitu masih banyaknya para pejabat pemerintah yang selalu menyalagunakan wewenangnya dengan melakukan tindakan korupsi yang membuat negara rugi dan membuat rakyat semakin menderita.

\subsubsection{Kritik Sosial Terhadap Penegak Hukum}

Dari keempat lirik lagu Iwan Fals yang menjadi fokus penelitian dalam penelitian ini, terdapat satu lirik lagu yang mengandung tentang kritik sosial terhadap penegak hukum yaitu terdapat pada lirik lagu Iwan Fals yang berjudul Tikus-tikus Kantor. Pada lirik lagu ini selain menggambarkan tentang para pejabat pemerintah yang selalu melakukan tindakan korupsi, juga menggambarkan tentang kurangnya kinerja penegak hukum dalam menjalankan tugasnya.

Kritik sosial terhadap penegak hukum terdapat pada bait kelima sampai bait keenam. Bait kelima yaitu sebagai berikut.

Kucing kucing yang kerjanya molor

Tak ingat tikus kantor datang menteror

Cerdik licik tikus bertingkah tengik

Mungkin karena sang kucing pura pura mendelik

Pada bait kelima tersebut menjelaskan aparat penegak hukum yang digambarkan dengan kata kucing. Adapun pengarang memilih kata kucing untuk disimbolkan sebagai penegak hukum karena pada realistasnya baik kucing maupun penegak hukum sama-sama mengawasi mangsanya, kucing mengawasi tikus dan penegak hukum mengawasi pelaku kriminal.

Dalam kinerjanya penegak hukum berkewajiban dalam melakukan pencegahan dan pengamanan terhadap tindakan-tindakan yang melawan hukum.Tetapi pada kutipan lirik di atas menjelaskan bahwa penegak hukum yang dinilai memiliki kinerja yang buruk dalam mengatasi kasus korupsi.

Penegak hukum dalam hal ini sebagai seorang yang bertindak sebagai pengadil justru terkesan seolah-olah melakukan pembiaran terhadap praktek-praktek korupsi yang dilakukan sang koruptor. Praktekpraktek tersebut pun pada prinsipnya disadari oleh penegak hukum.Arti, kata molor yang dimaksudkan pada kutipan lirik tersebut bisa jadi suatu hal yang disengaja. Penegak hukum terkesan mengamini apa yang dilakukan oleh koruptor bahkan mereka tidak pernah peduli terhadap akibat perilaku koruptor terhadap satabilitas 
negaranya. Hukum yang terjadi di negara ini sudah tidak berjalan lagi sesuai dengan prosedur atau kinerja penegak hukum. Seperti halnya pada bait keenam yaitu.

Tikus tau sang kucing lapar

Kasih roti jalanpun lancar

Memang sial sang tikus teramat pintar

Atau mungkin si kucing yang kurang

ditatar

Pada bait di atas menjelaskan bahwa para penegak hukum memang benar-benar di bawah kendali para koruptor. Para koruptor tahu aparat penegak hukum pun ingin melakukan hal yang sama yaitu korupsi dengan mereka. Dalam hal ini, mungkin aparat penegak hukum tidak melakukan langsung korupsi itu, tetapi mereka berharap mendapatkan bagian dari hasil korupsi itu.Para penegak hukum pun dianggap sangat mudah untuk disuap oleh para koruptor dalam melancarkan aksinya. Kata roti pada kuripan lirik diatas bisa dimaknai dengan sesuatu yang berharga yang diberikan oleh koruptor pada penegak hukum agar bisa bekerja sama untuk memuluskan jalannya.

Penjelasan dari bait kelima dan keenam pada lirik lagu Iwan Flas yang berjudul Tikus-tikus Kantor tersebut jelas mengandung kritik sosial terhadap penegak hukum. Lirik lagu ini masih sangat berhubungan dengan keadaan di lingkungan masyarakat Indonesia sekarang khususnya pada bidang hukum. Yaitu masih buruknya kinerja para penegak hukum, bukan hanya dalam memberantas korupsi tetapi juga pada hal-hal lainnya yang kinerjanya bisa dikatakan tumpul diatas runcing di bawah.

\subsubsection{Kritik Sosial Terhadap Pengangguran}

Dari keempat lirik lagu Iwan Fals yang menjadi fokus penelitian dalam penelitian ini, terdapat satu lirik lagu yang mengandung tentang kritik sosial terhadap pengangguran yaitu terdapat pada lirik lagu Iwan Fals yang berjudul Sarjana Muda.

Kritik sosial terhadap pengangguran terdapat pada bait ketiga sampai bait keempat yaitu sebagai berikut.

Engkau sarjana muda

Resah mencari kerja

Mengandalkan ijazahmu

Empat tahun lamanya

Bergelut dengan buku

Tuk jaminan masa depan

Langkah kakimu terhenti

Didepan halaman sebuah jawatan

Terjenuh lesu engkau melangkah

Dari pintu kantor yang diharapkan

Terngiang kata tiada lowongan

Untuk kerja yang didambakan

Pada bait tersebut menjelaskan tentang nasib sarjana muda di Indonesia yang banyak menjadi pengangguran. Susahnya perjuangan seorang sarjana yang mencari pekerjaan dengan membawa ijazah.Ijazah yang didapatkan selama empat tahun dengan menekuni dan mendalami buku dalam perkuliahan di perguruan tinggi seakan tidak berguna dalam mencari pekerjaan. Seseorang yang belajar di perguruan tinggi hingga menjadi sarjana bermaksud menjamin masa depannya kelak menjadi baik, akan tetapi pada kenyataanya tidak sesuai dengan apa yang diharapkan. Seorang sarjana dengan membawa ijazah dari kantor ke kantor untuk mendapatkan pekerjaan tetapi tidak ada lowongan kerja yang didapatkannya.

Berdasarkan deskripsi di atas, terlihat jelas bahwa kritik sosial pada lirik lagu Sarjana Muda mengandung kritik sosial terhadap penganguran. Di mana dalam lirik lagu tersebut menggambarkan susahnya perjuangan seorang sarjana dalam mencari kerja dari kantor ke kantor dengan membawa ijazah namun tidak mendapatkan pekerjaan. Dan lirik lagu tersebut juga masih berhubungan dengan keadaan masyarakat di 
Indonesia sekarang khususnya dalam bidang ekonomi, yaitu masih banyaknya lulusan sarjana yang menjadi pengangguran yang disebabkan minimnya lapangan pekerjaan yang disediakan oleh pemerintah.

\subsubsection{Kritik Sosial Terhadap Kinerja Anggota Dewan}

Dari keempat lirik lagu Iwan Fals yang menjadi fokus penelitian dalam penelitian ini, terdapat satu lirik lagu yang mengandung tentang kritik sosial terhadap kinerja anggota dewan yaitu terdapat pada lirik lagu Iwan Fals yang berjudul Surat Buat Wakil Rakyat.

Lagu Surat Buat Wakil Rakyat ini diciptakan pada tahun 1987 dan di populerkan pada album Wakil Rakyat. Lirik lagu ini mengisahkan tentang anggota dewan yang bekerja tidak sebagaimana mestinya, yang mana pekerjaannya untuk menyampaikan keluhan-keluhan atau aspirasi-aspirasi masyarakat kepada pemerintah tetapi pada kenyataanya anggota dewan tidak menyampaikan hal itu kepada pemerintah apa yang telah dikelukan oleh masyarakat. Sikap dan kinerja para anggota dewan atau wakil rakyat sudah tidak sesuai dengan tugas dan kewajiban mereka sebagai wakil rakyat. Kritik sosial terhadap kinerja anggota dewan terdapat pada bait kesatu sampai bait kedelapan. Bait kesatu dan kedua yaitu.

Untukmu yang duduk sambil diskusi

Untukmu yang biasa bersafari

Disana di gedung DPR

Wakil rakyat kumpulan orang hebat

Bukan kumpulan teman teman dekat

Apalagi sanak famili

Pada bait di atas jelas-jelas menyinggung para anggota dewan yang berada di gedung DPR. Bahwa untuk menjadi seorang anggota dewan harus memiliki kecerdasan, pendidikan yang tinggi serta memiliki pemikiran yang
luas.Namun dalam lirik lagu diatas menunjukan kritikan adanya hubungan kekerabatan atau adanya nepotisme yang ada di gedung DPR pada kala itu. Anggota dewan seakan lupa akan kewajiban mereka yaitu mendahulukan kepentingan negara atas kepentingan pribadi, kelompok dan golongan. Di sisi lain juga anggota dewan seakan tidak perduli lagi dengan aspirasiaspirasi rakyat, seperti yang terjadi pada bait ketiga dan keempat berikut.

Dihati dan lidahmu kami berharap

Suara kami tolong dengar lalu

sampaikan

Jangan ragu jangan takut karang

menghadang

Bicaralah yang lantang jangan hanya

diam

Dikantong safarimu kami titipkan

Masa depan kami dan negeri ini

Dari Sabang sampai Merauke

Pada bait di atas mendeskripsikan bahwa rakyat yang menyampaikan keluhan-keluhan atau aspirasi-aspirasinya kepada pemerintah melalui para anggota dewan, dengan harapan anggota dewan mendengarkan dan menyampaikan aspirasi rakyat dengan tegas dan jelas kepada pemerintah. Sesuai dengan fungsi kewajiban anggota DPR yaitu memperjuangkan peningkatan kesejahteraan rakyat, serta menampung dan menindak lanjuti aspirasi dan pengaduan masyarakat.Tetapi pada kenyataannya para anggota dewan tidak memperjuangkan, menyuarakan keluhan ataupun aspirasi rakyat kepada pemerintah demi kesejateraan rakyat di negeri ini. Seperti pada bait ke lima berikut.

Saudara dipilih bukan di lotere

Meski kami tak kenal siapa saudara

Kami tak sudi memilih para juara

Juara diam juara he eh juara hahaha

Pada bait di atas menjelaskan bahwa anggota dewan dipilih oleh rakyat tanpa mengenal siapa mereka melalui pemilihan

441 |Jurnal BASTRA (Bahasa dan Sastra), Vol. 4 No. 3, Edisi Juli 2019/e-ISSN: 2503-3875/ http://ojs.uho.ac.id/index.php/BASTRA 
umum dan diberikan amanat untuk tegas dalam mengambil keputusan yang adil dan amanat sesuai dengan fungsi dan tangung jawab mereka. Akan tetapi semua itu jauh dari harapan rakyat, para anggota dewan di gedung DPR hanya datang, duduk/tidur, diam dan dibayar. Seperti pada bait kedelapan berikut.

Wakil rakyat seharusnya merakyat

Jangan tidur waktu sidang soal rakyat

Wakil rakyat bukan paduan suara

Hanya tahu nyanyian lagu "setuju"

Pada bait di atas menjelaskan bahwa rakyat mengharapkan kesadaran dari anggota dewan agar dapat memperjuangkan kesejahteraan rakyat, mendengarkan dan menyampaikan aspirasi rakyat dengan tegas kepada pemerintah sesuai dengan fungsi dan tanggung jawab mereka. Diharapkan juga kepada anggota dewan agar tidak tidur saat sidang mengenai rakyat, tidak hanya mengikuti arus dan harus memiliki inisiatif sendiri terhadap memperjuangan hak-hak rakyat demi kesejahteraan negara ini.

Berdasarkan dari beberapa deskripsi di atas, maka kritik sosial yang terdapat pada lagu Surat Buat Wakil Rakyat yaitu kritik sosial terhadap kinerja anggota dewan.Yang mana dalam lirik lagu tersebut menggambarkan sikap dan kinerja para anggota dewan atau wakil rakyat sudah tidak sesuai dengan tugas dan kewajiban mereka sebagai wakil rakyat.Dan lirik lagu ini masih sangat berhubungan dengan kinerja anggota dewan di Indonesia sekarang ini khususnya dalam bidang politik.

\subsubsection{Kritik Sosial Terhadap}

\section{Diskriminasi Pelayanan Kesehatan}

Dari keempat lirik lagu Iwan Fals yang menjadi fokus penelitian dalam penelitian ini, terdapat satu lirik lagu yang mengandung tentang kritik sosial terhadap diskriminasi pelayanan kesehatan yaitu terdapat pada lirik lagu Iwan Fals yang berjudul Ambulance Ziz-zag. Kritik sosial terhadap diskriminasi pelayanan kesehatan terdapat pada bait kesatu sampai bait kesepuluh. Bait kesatu sampai kelima yaitu sebagai berikut.

Deru ambulance

Memasuki pelataran rumah sakit

Yang putih berkilau

Di dalam ambulance tersebut

Tergolek sosok tubuh gemuk

Bergelimang perhiasan

Nyonya kaya pingsan

Mendengar kabar

Putranya kecelakaan

Dan para medis

Berdatangan kerja cepat

Lalu langsung membawa korban menuju

ruang periksa

Tanpa basa basi

Ini mungkin sudah terbiasa

Pada bait di atas mendeskripsikan bahwa pelayanan kesehatan pasien rumah sakit dengan status ekonomi yang menengah ke atas yaitu tanpa basa-basi tim medis menangani dengan sangat ramah, baik dan cepat dengan di tempatkan ruangan rumah sakit kelas atas. Lain halnya dengan perlakuan pada pasien yang status ekonominya ke bawah, seperti pada keenam sampai bait kesepuluh berikut.

Tak lama berselang

Supir helicak datang

Masuk membawa korban yang berkain sarung

Seluruh badannya melepuh

Akibat pangkalan bensin ecerannya

Meledak

Suster cantik datang

Mau menanyakan

Dia menanyakan data si korban

Di jawab dengan

Jerit kesakitan

Suster menyarankan bayar ongkos

pengobatan

Ai sungguh sayang korban tak bawa

442 |Jurnal BASTRA (Bahasa dan Sastra), Vol. 4 No. 3, Edisi Juli 2019/e-ISSN: 2503-3875/ http://ojs.uho.ac.id/index.php/BASTRA 
uang

Suster cantik ngotot

Lalu melotot

Dan berkata silahkan bapak tunggu di muka

Pada bait di atas mendeskripsikan bahwa pelayanan pasien dengan status ekonomi di bawah tidak mendapatkan pelayanan kesehatan seperti yang diterima oleh pasien dengan status ekonominya menengah atas. Pasien dengan status ekonominya dibawah sering mendapatkan pelayanan yang kurang baik, fasilitas yang mereka dapatkan pun sangat terbatas.Belum lagi pelayanan kesehatan yang di berikan kepada mereka sering kali terlambat dan tidak di prioritaskan, sehingga tidak mengherankan jika kita sering mendengar mereka terlantarkan di rumah sakit.

Berdasarkan beberapa deskripsi dari bait lirik lagu di atas, maka kritik sosial yang terdapat pada lagu ambulance zig-zag ini yaitu kritik sosial terhadap diskriminasi pelayanan kesehatan. Dalam lirik lagu tersebut menggambarkan pelayanan kesehatan yang masih pandang bulu antara pasien kaya dan pasien yang kurang mampu, bisa dikatakan kesehatan yang di dapat seseorang tergantung dari tebal tipisnya kantong pasien.Pada lirik lagu tersebut juga masih berhubungan dengan keadaan pelayanan kesehatan yang di dapatkan oleh masyarakat sekarang, dalam pelayanan kesehatan pasien kaya selalu diutamakan dan pasien yang kurang mampu selalu dikebelakangkan, sehingga banyak pasien yang kurang mampu di terlantarkan di rumah sakit.

\section{PENUTUP}

\subsection{Kesimpulan}

Berdasarkan hasil penelitian dan pembahasan mengenai kritik sosial yang terdapat pada lirik lagu Tikus-tikus Kantor, Sarjana Muda, Surat Buat Wakil Rakyat dan
Ambulance Zig-zag karya Iwan Fals, dengan menggunakan pendekatan sosiologi karya sastra dapat disimpulkan sebagai berikut.

Kritik sosial pada lirik lagu Tikus-tikus Kantor, Sarjana Muda, Surat Buat Wakil Rakyat dan Ambulance Zig-zag karya Iwan Fals di deskripsikan sebagai berikut:

1. Kritik sosial terhadap korupsi

2. Kritik sosial terhadap penegak hukum

3. Kritik sosial terhadap pengangguran

4. Kritik sosial terhadap kinerja anggota dewan

5. Kritik sosial terhadap diskriminasi pelayanan kesehatan

\subsection{Saran}

Berdasarkan hasil penelitian dan kesimpulan dalam penelitian ini, maka penelitian mengajukan saran sebagai berikut:

1. Perlu adanya peningkatan dalam penelitian sastra khususnya pada lirik lagu yaitu mengenai kritik sosial atau masalah sosial, dengan begitu peneliti dan pembaca dapat memahami masalah yang cenderung terjadi dalam kehidupan masyarakat.

2. Pembaca karya sastra sebaiknya mengambil nilai-nilai positif yang terdapat dalam karya sastra tersebut, kemudian diaplikasikan dikehidupan sehari-hari.

3. Karena begitu banyak masalah-masalah sosial yang terjadi di lingkungan masyarakat di negeri kita ini, maka penulis menyarankan agar pelajaran tentang nilai, agama, moral, dan akhlak budi pekerti perlu ditingkatkan lagi terutama di dunia pendidikan.

\section{DAFTAR PUSTAKA}

Anwar, Ahyar. 2010. Teori Sosial Sastra. Yogyakarta: Ombak. 
Esten, Musral. 2013. Kesusastraan (Pengantar Teori dan Sejarah). Bandung: Angkasa.

Faruk. 2017. Pengantar Sosiologi Sastra (dari Strukturalisme Genetik sampai Post-modernisme). Yogyakarta: Pustaka Pelajar.

Jabrohim. 2014. Teori Penelitian Sastra. Yogyakarta. Pustaka Pelajar.

Pradopo, Rachmat Djoko. 2007. PrinsipPrinsip Kritik Sastra. Yogyakarta: Gadjah Mada University Press.

Pradopo, Rachmat Djoko. 2013. Beberapa Teori Sastra, Metode Kritik, dan Penerapannya. Yogyakarta: Pustaka Pelajar

Ratna, Nyoman Kutha. 2008. Teori, Metode, dan Teknik Penelitian Sastra. Yogyakarta: Pustaka Pelajar.

Ratna, Nyoman Kutha. 2009. Paradigma Sosiologi Sastra. Yogyakarta: Pustaka Pelajar.

Redaksi PM. 2012. Sastra Indonesia Paling Lengkap. Depok: Pustaka Makmur

Santoso, Didik Ardi. 2014. Aransemen dan Kritik Sosial Lagu-lagu Koes Plus Volume 1 Tahun 1969.http://journal.unn es.ac.id/sju/index.php/catharss Diakses pada tanggal 22 November 2018.

Semi, Atar. 1990. Metode Penelitian Sastra. Bandung: Angkasa.

Siswanto, Wahyudi. 2008. Pengantar Teori Sastra. Jakarta: Grasindo

Sumardjo, Jakob dan Saini K.M. 1997.Apresiasi Kesusastraan. Jakarta: Gramedia Pustaka Utama.

Suwondo, Tirto. 2011. Studi Sastra (Konsep Dasar Teori dan Penerapannya pada Karya Sastra). Yogyakarta: Gama Media.

Wellek, Rene dan Austin Warren. 2016. Teori Kesusastraan (di Indonesiakan oleh Melani Budianta). Jakarta: Gramedia Pustaka Utama.
Wicaksono, Andri. 2014. Pengkajian Prosa Fiksi. Yogyakarta: Garudhawaca. 